\title{
Removal of Cyanobacteria Toxins from Drinking Water by Adsorption on Activated Carbon Fibers
}

\author{
Eden Cavalcanti de Albuquerque Júnior ${ }^{\mathrm{a} *}$, Manoel Orlando Alvarez Méndez $z^{\mathrm{b}}$ \\ Aparecido dos Reis Coutinho ${ }^{\mathrm{b}}$, Telma Teixeira Franco ${ }^{\mathrm{a}}$
}

\author{
${ }^{a}$ School of Chemical Engineering, State University of Campinas - UNICAMP, \\ CP 6066, 13081-970 Campinas - SP, Brazil \\ ${ }^{\mathrm{b}}$ Laboratory of Carbon Materials, Methodist University of Piracicaba - UNIMEP, \\ 13450-000 Santa Bárbara d'Oeste - SP, Brazil
}

Received: February 27, 2008; Revised: August 5, 2008

\begin{abstract}
Natural fibers from macadamia nut shell, dried coconut shell endocarp, unripe coconut mesocarp, sugarcane bagasse and pine wood residue were used to prepare activated carbon fibers (ACF) with potential application for removing microcystins. The ACF from pine wood and sugar cane bagasse were used to remove [D-Leucine $\left.{ }^{1}\right]$ MCYST-LR from water. After 10 minutes of contact time, more than $98 \%$ of toxin was removed by the ACF. The microcystin adsorption monolayer, $\mathrm{q}_{\mathrm{m}}$, in the ACF recovered 200 and $161 \mu \mathrm{g} \cdot \mathrm{mg}^{-1}$, with the Langmuir adsorption constant, $\mathrm{K}_{\mathrm{L}}$, of 2.33 and $1.23 \mathrm{~L} \cdot \mathrm{mg}^{-1}$. Adsorption of [D-Leucine ${ }^{1}$ ]MCYST-LR in continuous process was studied for a fixed-bed ACF prepared from coconut shell and sugar cane bagasse and for two commercial activated carbon samples from treatment water plants of two Brazilian hemodialysis centers. Saturation of the beds occurred after 80 to 320 minutes, and the adsorption capacity for that toxin varied from 4.11 to $12.82 \mu \mathrm{g} . \mathrm{mg}^{-1}$.
\end{abstract}

Keywords: activated carbon fibers, cyanobacteria, microcystins, adsorption, hemodialysis

\section{Introduction}

Cyanobacteria are prokaryotic organisms found on aquatic environments used as water supply as well as recreation throughout the World, including Brazil1 ${ }^{1-2}$. Cyanobacteria strains like Microcystis, Nodularia, Cylindrospermopsis, Anabaena and Aphanizomenon spp. are recognized by producing toxins such as microcystins (MCYSTs), nodularins, cylindrospermopsins, anatoxins and Paralytic Shellfish Poisons (PSP) ${ }^{3}$.

Conventional water treatment processes involving coagulation, filtration and sedimentation steps, have been shown to be partially efficient in removing cyanobacteria toxins from drinking water, but the use of powdered or granulated activated carbon (AC) in association with these processes has been shown to increase this efficiency ${ }^{4-7}$.

Despite being widely used as an adsorbent in water treatment and in other industrial applications, activated carbons are relatively expensive materials. According to the Secretary of Commerce of the Ministry of Industrial Development and Foreign Commerce, until 2006 the Brazil came exporting annually an average of 1,908,507 t of activated carbon at an average cost of US\$ FOB (free of transport costs) 69.63. $\mathrm{t}^{-1}$. However, Brazil also imports 2,377,198 t/year of these materials at a mean cost of US\$ FOB $143.15 . \mathrm{t}^{-1}$, twice the exportation price $^{8}$. In this context, the need to develop technology for the production of high quality activated carbons, preferably from low cost raw materials, is apparent, in order to substitute these importations.

The purpose of the present work was to study the adsorption capacity of activated carbon fibers obtained from natural fibers of agricultural residues using batch and continue adsorption process for removal of a cyanobacteria hepatotoxin, [D-Leucine $\left.{ }^{1}\right]$ MCYST-LR, isolated and identified in two Brazilian regions: Patos Lagoon estuary, RS, Brazil and Jacarepaguá Lagoon estuary, RJ, Brazil ${ }^{9,10}$.

\section{Experimental Procedures}

\subsection{Production of the activate carbon fibers}

Lignocellulosic natural fibers from pine wood residues (PWR) (Pinus taeda), macadamia nutshell (MNS) (Macadamia integrifolia), dried coconut shell endocarp (CS) (Cocus nucifera), unripe coconut mesocarp (UCM) (Cocus nucifera) and sugar cane bagasse (SCB) (Saccharum sp.) were used to produce high quality activated carbon fibers (ACF). The starting materials were carbonized and activated in steam at temperatures near to $900{ }^{\circ} \mathrm{C}$. Albuquerque Junior et al. $(2005)^{11}$ published the details for the preparation of these materials, their carbonization and activation, and also characterized them in the liquid and gaseous phases. Three commercial activated carbons used on the water treatment were used as reference material, and they were gently donated from Brascarbo Ltda, Guarapuava-PR, Brazil (NORIT GAC $12 \times 40$ ), Hemodialysis center at the Clinical Hospital of the Federal University of Pernambuco, Recife, PE, Brazil (Carboleste, activated carbon F) and Hemodialysis center at the Clinical Hospital of the State University of Campinas, Campinas, São Paulo, Brazil (CALGON, activated carbon B).

\subsection{Characterization of the ACF and commercial AC}

Samples of ACF and commercial AC were degassed under vacuum at $150{ }^{\circ} \mathrm{C}$ until completely dry. A gas adsorption analyzer (Quantachrome Corp. model NOVA-1200) was used to measure the pore distribution, pore volume and Specific Surface Area (SSA). Nitrogen adsorption/desorption isotherm data at $-196{ }^{\circ} \mathrm{C}$ were used to determine the SSA according to the method proposed by Brunauer, Emmet and Teller $(B E T)^{12}$. The micropore area $\left(\mathrm{d}_{\mathrm{i}} \leq 2.0 \mathrm{~nm}\right)$ was 
obtained by applying the t-plot method. The total pore volume was determined by converting the volume adsorbed at the saturation point $\mathrm{P} / \mathrm{P}_{0} \sim 0.99$ into liquid volume, while the micropore $\left(\mathrm{d}_{\mathrm{i}} \leq 2.0 \mathrm{~nm}\right)$ and primary micropore $\left(\mathrm{d}_{i} \leq 0.8 \mathrm{~nm}\right)$ volumes were calculated at the point of interception of the linear region of the t-plot after saturation of the micropores and primary micropores, respectively. The mesopore volume $\left(2.0 \mathrm{~nm} \leq \mathrm{d}_{\mathrm{i}} \leq 50 \mathrm{~nm}\right)$ was calculated from the difference between the total pore volume and the micropore volume, and the secondary micropore volume $\left(0.8 \leq \mathrm{d}_{\mathrm{i}} \leq 2.0 \mathrm{~nm}\right)$ from the difference between the micropore volume and the primary micropore volume ${ }^{12}$.

Fourier transform infrared spectroscopy (FTIR) is used to qualitatively identify the surface functional groups of ACF. The transmission spectra of the ACF samples were recorded using $\mathrm{KBr}$ pellets with $0.5 \%$ carbon. The spectra were measured from 400 to $4000 \mathrm{~nm}$ and recorded on a BOMEM MB100 FTIR spectrometer (ABB, Zurich, Switzerland).

\subsection{Extract of microcystins}

To study the adsorption kinetics and equilibrium of [D-Leucine ${ }^{1}$ ] MCYST-LR by the ACF, a crude extract of microcystins obtained from a toxic strain of Microcystis sp. was prepared. An inoculum of the cyanobacterial strain (NPLJ-4) isolated in Jacarepaguá Lagoon estuary was provided by the Cyanobacteria Eco-physiology and Toxicology Laboratory of the Carlos Chagas Filho Institute of Biophysics - Federal University of Rio de Janeiro (LECT-UFRJ) and it was grown in the Laboratory of Hydraulics and Sanitation of the School of Engineering, USP, São Carlos, Brazil, using the growth conditions described by Kuroda et al. $(2005)^{13}$. When cell density attained the order of $10^{7}$ cells. $\mathrm{mL}^{-1}$, the cultures were submitted to a freezing and thawing process three times to promote cell lysis and liberation of the intracellular microcystins into the medium. After the freezing/thawing process, the cell extract was centrifuged at 10,000 RPM (rotation per minute) for 10 minutes. The supernatant was filtered through a $0.2 \mu \mathrm{m}$ mesh membrane in polyvinylidene fluoride (PVDF) (millex, Millipore, USA) to separate the particulate material. After homogenizing the extracts, they were divided into $1 \mathrm{~L}$ (E1) aliquots and stored at $-20{ }^{\circ} \mathrm{C}^{14}$.

The adsorbate solution, a MCYST extract with a concentration close to $11.0 \mathrm{mg} . \mathrm{L}^{-1}$ (E2), was prepared by concentrating the extract (E1) in a vacuum rotary evaporator at $45^{\circ} \mathrm{C}$. The residue was resuspended in phosphate buffer $(\mathrm{pH}$ 7.0) prepared with chlorine-free drinking water and passed through a $0.2 \mu \mathrm{m}$ membrane and then used in the adsorption kinetics and equilibrium experiments.

\subsection{Adsorption kinetics of [D-Leucine $\left.{ }^{1}\right]$ MCYST-LR}

In order to quantify the kinetics evolution and equilibrium time of the adsorption of [D-Leucine ${ }^{1}$ MCYST-LR by the ACF from pine wood, sugarcane bagasse and dried coconut shell endocarp, the method using finite bath immersion was employed ${ }^{15}$. Thus in each experiment, 2 to $5 \mathrm{mg}( \pm 0.1 \mathrm{mg})$ of the ACF from pine wood, sugarcane bagasse, dried coconut shell endocarp and the two commercial $\mathrm{AC}(\mathrm{AC} \mathrm{B}$ and $\mathrm{F}$ ) from hemodialysis centers were weighed and made up to solutions with final concentrations of 200 to $1000 \mathrm{mg} . \mathrm{L}^{-1}$ (ACF mass per volume of extract). The extract of Microcystins $(10 \mathrm{~mL})$, with initial [D-Leucine ${ }^{1}$ ]MCYST-LR concentrations between 6.3 and $11.0 \mathrm{mg} . \mathrm{L}^{-1}$ depending on the ACF or commercial AC studied, were added to the flasks. The flasks were then sealed and shaken in an orbital shaker at $25\left( \pm 1{ }^{\circ} \mathrm{C}\right)$ and a speed of $260 \mathrm{RPM}$ (rotation per minute). Aliquots were removed from these flasks after 5 seconds and up to 60 minutes for the above cited study. The samples were passed through a PVDF $0.45 \mu \mathrm{m}$ filter adapted on a syringe (millex, Millipore, USA) to remove particulate material and the residual concentration of the toxin in the solution at each time period determined by HPLC using the UV detector at $238 \mathrm{~nm}^{14}$. The trials were carried out in triplicate and the amount of adsorbed toxin onto the surface of the carbons (q) calculated from Equation 1.

$$
\mathrm{q}=\left(\frac{\mathrm{C}_{0}-\mathrm{C}}{\mathrm{m}}\right) \times V
$$

where $\mathrm{q}$ is the mass of adsorbed toxin $(\mu \mathrm{g})$ per mass of ACF or commercial $\mathrm{AC}(\mathrm{mg}), \mathrm{C}_{0}$ and $\mathrm{C}$ are the initial and equilibrium concentrations of the toxin in the liquid phase, $\mathrm{V}$ is the volume of the solution and $\mathrm{m}$ the mass of adsorbent ( $\mathrm{mg}$ ).

Three kinetic models, i.e. the Lagergren-first-order (Equation 2), pseudo-second-order (Equation 3) and Elovich (Equation 4), were considered to interpret the time dependent experimental data ${ }^{16-18}$.

$$
\begin{aligned}
& \frac{t}{q_{t}}=\frac{1}{k_{2} q_{2}^{2}}+\frac{1}{q_{2}} t \\
& \frac{d q_{t}}{d t}=\alpha \exp \left(-\beta q_{t}\right)
\end{aligned}
$$$$
\operatorname{In}\left(\mathrm{q}_{1}-\mathrm{q}_{\mathrm{t}}\right)=\operatorname{In}\left(\mathrm{q}_{1}\right)-\mathrm{k}_{1} \mathrm{t}
$$

To simplify the Elovich equation, Chien and Clayton ${ }^{19}$ assumed $\alpha \beta t$ » 1 and by applying the boundary conditions $q_{t}=0$ at $t=0$ and $\mathrm{q}_{\mathrm{t}}=\mathrm{q}_{\mathrm{t}}$ at $\mathrm{t}=\mathrm{t}$, Equation (4) becomes:

$$
\frac{d q_{t}}{d t}=\frac{1}{\beta} \ln (\alpha \beta)+\frac{1}{\beta} \ln t
$$

where $\mathrm{q}_{1}$ and $\mathrm{q}_{\mathrm{t}}$ are the amounts of [D-Leu ${ }^{1}$ MCYST-LR adsorbed on the adsorbents at equilibrium and at various times $\mathrm{t}\left(\mu \mathrm{g} \cdot \mathrm{g}^{-1}\right), \mathrm{k}_{1}$ is the rate constant of the Lagergren-first-order model for the adsorption process (per minute) $\mathrm{q}_{2}$ is the maximum adsorption capacity $\left(\mu \mathrm{g} . \mathrm{g}^{-1}\right)$ and $\mathrm{k}_{2}$ is the rate constant for the pseudo-second-order model (mg. $\left.\mu \mathrm{g}^{-1} / \mathrm{min}\right) ; \alpha$ is the initial adsorption rate ( $\left.\mu \mathrm{g} . \mathrm{g}^{-1} / \mathrm{min}\right)$ and $\beta$ is the desorption constant $\left(\mathrm{mg} \cdot \mu \mathrm{g}^{-1}\right)$ for Elovich model.

\subsection{Adsorption equilibrium of [D-Leucine $\left.{ }^{1}\right]$ MCYST-LR}

As from the kinetics evolution and equilibrium time study for the ACF from pine wood and sugarcane bagasse, which were more mesoporous than the ACF from dried coconut shell endocarp, and two commercial AC, it was possible to estimate the adsorption capacity of these adsorbents for the [D-Leucine $\left.{ }^{1}\right]$ MCYST-LR. Thus the adsorption equilibrium experiments were carried out in $15.0 \mathrm{~mL}$ screw top amber flasks, adding a $10 \mathrm{~mL}$ volume of the extract (E2) with an initial toxin concentration of 6.5 or $10 \mathrm{mg} . \mathrm{L}^{-1}$ for the pine wood and bagasse $\mathrm{ACF}$, respectively. The ACF concentrations varied from 0.5 to $700 \mathrm{mg} . \mathrm{L}^{-1}$ and the dilutions were prepared from a suspension with an initial concentration of $1 \mathrm{~g} . \mathrm{L}^{-1}$. The ACF/toxin system was shaken at $260 \mathrm{RPM}$ at $25 \pm 1{ }^{\circ} \mathrm{C}$ for the time required to reach equilibrium, when a aliquot of each sample was removed, passed through a $0.45 \mu \mathrm{m}$ filter (millex, Millipore, EUA) and reserved for the HPLC determination of the residual toxin concentration at equilibrium. The experiments were carried out in triplicate and the experimental data fitted to the Freundlich's and Langmuir's models ${ }^{12}$. These models are usually the most used and can be expressed as shown in Equation 6 and 7.

$$
\begin{gathered}
\mathrm{q}=\frac{\mathrm{q}_{\mathrm{m}} \mathrm{k}_{\mathrm{L}}}{1+\mathrm{k}_{\mathrm{L}} \mathrm{C}_{\mathrm{e}}} \\
\mathrm{Q}=\mathrm{k}_{\mathrm{F}} \mathrm{C}_{\mathrm{e}}^{\frac{1}{\mathrm{n}}}
\end{gathered}
$$


where $\mathrm{q}$ and $\mathrm{Q}$ are adsorbed quantity, $\mathrm{k}_{\mathrm{L}}$ and $\mathrm{k}_{\mathrm{F}}$ are constants obtained from by Langmuir and Freundlich model's, $\mathrm{q}_{\mathrm{m}}$ is adsorbed quantity on mono layer, $\mathrm{C}_{\mathrm{e}}$ is concentration at equilibrium and $\mathrm{n}$ is the affinity constant.

\subsection{Dynamic adsorption of [D-Leucine $\left.{ }^{1}\right]$ MCYST-LR on ACF fixed-bed}

To evaluate the dynamic adsorption of [D-Leucine $\left.{ }^{1}\right]$ MCYSTLR on the ACF fixed-bed, an acrylic custom-made column $(25.0 \mathrm{x}$ $2.5 \mathrm{~cm}$ I.D.) was used, where the bed height was fitted with an adjustable piston. A perforated distributor was put at the bottom of the column. It was made of stainless steel with five orifices $1.0 \mathrm{~mm}$ in diameter giving a $0.8 \%$ open area ratio. A $60 \mu \mathrm{m}$ mesh was used both below the perforated plate distributor and on the inner piston surface in order to avoid loss of adsorbent by backflow or by elutriation, respectively. A ruler was put on the column wall in order to help the bed height record. Figure 1 illustrates a diagram of the column used in this work. The column was coupled to a system, which consisted basically of a mixer and a controller as well as a peristaltic pump (P-50) that allows obtaining flow rates from 0.1 to $50.0 \mathrm{~mL} / \mathrm{min}$.

Adsorption capacity of the ACF fixed-bed was evaluated by breakthrough curves, constructed as $\mathrm{C} / \mathrm{C}_{0}$ vs. time, and the $\mathrm{ACF}$ used in this study were those obtained from sugarcane bagasse and dried coconut shell endocarp, besides two commercial AC used in water treatment plant on Brazilian hemodialysis centers (AC B and AC F).

Table 1 shows experimental conditions of the [D-Leucine ${ }^{1}$ ] MCYST-LR dynamic adsorption on ACF fixed-bed, where $\mathrm{C}_{0}$ is feed concentration of microcystin $\left(\mu \mathrm{g} . \mathrm{L}^{-1}\right)$ in the column, $\mathrm{h}_{\mathrm{B}}$ is bed height and $m_{z}$ is ACF mass of the bed $(\mathrm{g})$. The microcystin concentration in the exit of the column was monitored up to the exhaustion using HPLC-UV at $238 \mathrm{~nm}^{14}$.

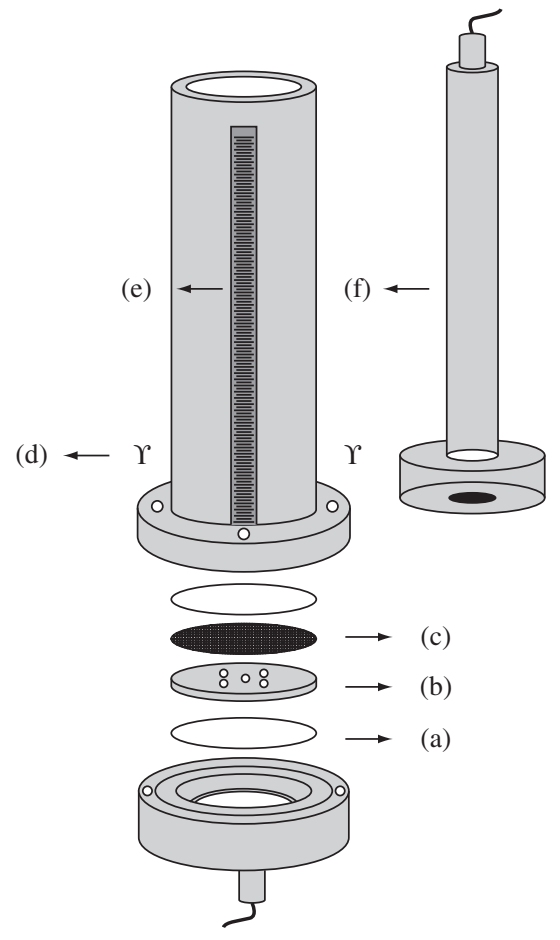

Figure 1. Drawing of the column used in this work: a) rubber gasket, b) distributor (perforated plate), c) screen $(60 \mu \mathrm{m}), \mathrm{d})$ screw, e) ruler, and f) piston ${ }^{20}$.
According to Barros et al. (2001) $)^{21}$ the time equivalent to usable capacity of the bed $\left(\mathrm{t}_{\mathrm{u}}\right)$ and the time equivalent to total stoichiometric capacity of the packed bed $\left(\mathrm{t}_{\mathrm{t}}\right)$ if the entire bed attains to equilibrium are provided by a mass balance in the column (and are easily determined by:

$$
t_{u}=\int_{0}^{t_{B}}\left(1-\frac{C}{C_{0}}\right) d t \text { and } t_{t}=\int_{0}^{t_{\infty}}\left(1-\frac{C}{C_{0}}\right) d t
$$

where $t_{b}$ is the break-point time.

According to Geankoplis $(1993)^{22}, \mathrm{t}_{\mathrm{b}}$ is defined as the time when the effluent concentration $(\mathrm{C})$ reaches $5 \%$ of the influent concentration $\left(\mathrm{C}_{\mathrm{o}}\right)$ and the ratio $\mathrm{t}_{\mathrm{u}} / \mathrm{t}$ is the fraction of the total bed capacity or length utilized to the breakpoint. Hence, the length of unused bed is:

$$
H_{U N B}=\left(1-\frac{t_{u}}{t_{t}}\right) H_{t}
$$

where $\mathrm{Ht}$ is the total bed length.

Thus, the useful capacity of the ACF fixed-bed $\left(Q_{u}\right)$ was obtained from mass balance on the column, using the breakthrough curves up to the time on which $\mathrm{C} / \mathrm{C}_{0}=0.05$, and this represents the adsorbed quantity up to the breakthrough point, it is proportional to the area below of the curve up to the this point. The fixed-bed exhaustion capacity $\left(\mathrm{Q}_{\mathrm{t}}\right)$ was also obtained from the breakthrough curves up to the exhaustion point, $\mathrm{C} / \mathrm{C}_{0}=1$, calculated from total area above the curve, proportional to total quantity of solute adsorbed per adsorbent mass unit. Thus, using the Equation 10 and $11, \mathrm{Q}_{\mathrm{u}}$ e $\mathrm{Q}_{\mathrm{t}}$ are calculated.

$$
\begin{aligned}
& Q_{u}=\frac{C_{0} \times V}{1000 \times m} \int_{0}^{t_{5 \%}}\left(1-\frac{C}{C_{0}}\right) d t \\
& Q_{t}=\frac{C_{0} \times V}{1000 \times m} \int_{0}^{t_{t}}\left(1-\frac{C}{C_{0}}\right) d t
\end{aligned}
$$

\section{Results and Discussions}

\subsection{Production and characterization of the ACF}

\subsubsection{Surface area and porosity}

The process of single-stage steam activation and pyrolysis for the production of ACF was effective for obtaining adsorbents with SSA upper to the $1,000 \mathrm{~m}^{2} \cdot \mathrm{g}^{-1}$. We have shown from porosity results on Table 2 that the structure of the starting material was one of the main factors that determined the nature of the ACF produced. The results indicated that the structures of ACF from MNS, CS and UCM are well suited to the production of microporous $\mathrm{ACF}$, with a micropore area between 1,014.2 and 1,245.8 $\mathrm{m}^{2} \cdot \mathrm{g}^{-1}$ and a micropore volume between

Table 1. Experimental conditions for adsorption dynamic of [D-Leucine $\left.{ }^{1}\right]$ MCYST-LR on fixed-bed ACF.

\begin{tabular}{lcccc}
\hline \multicolumn{1}{c}{ Ref. } & $\mathrm{C}_{0}\left(\mathrm{mg} . \mathrm{L}^{-1}\right)$ & $\begin{array}{c}\text { Flow rate } \\
(\mathrm{mL} / \mathrm{min})\end{array}$ & $\mathrm{h}_{\mathrm{B}}(\mathrm{cm})$ & $\mathrm{m}_{\mathrm{z}}(\mathrm{g})$ \\
\hline $\mathrm{AC} \mathrm{B}^{*}$ & 12.8 & 11.1 & 2.4 & 8.3 \\
$\mathrm{AC} \mathrm{F}^{*}$ & 12.5 & 8.5 & 2.3 & 8.1 \\
$\mathrm{CS} \mathrm{ACF}$ & 13.4 & 10.5 & 2.4 & 9.2 \\
$\mathrm{SCB}$ ACF & 19.1 & 12.2 & 2.3 & 7.0 \\
\hline
\end{tabular}

*Commercial activated carbons sampled from hemodialysis centers at the Clinical Hospital of the State University of Campinas and Federal University of Pernambuco. 
0.34 and $0.55 \mathrm{~cm}^{3} \cdot \mathrm{g}^{-1}$, while the structures of SCB and PWR are well suited to the production of mesoporous ACF with a mesopore area between 77.3 and $342.5 \mathrm{~m}^{2} \cdot \mathrm{g}^{-1}$ and a mesopore volume between of 0.39 and $1.06 \mathrm{~cm}^{3} \cdot \mathrm{g}^{-1}$.

Commercial activated carbons were sampled to compare their porous characteristics with those ACF obtained in this work. Thus, these $\mathrm{AC}$ named $\mathrm{B}$ and $\mathrm{F}$ from water treatment plant at Clinical Hospital of the State University of Campinas and Federal University of Pernambuco, presented SSA of 871.2 and $789.5 \mathrm{~m}^{2} \cdot \mathrm{g}^{-1}$, (Table 2). From these results we could choose both commercial AC, however SSA is a poor indicator of the adsorption capacity on activated carbons ${ }^{23}$. Therefore, we can not evaluate the quality of the sampled activated carbons only from SSA data; we may consider others parameters to choose an AC for one specific process such as water treatment.

Therefore, in addition to ASS, the volumetric fractions of mesopores and secondary micropores should also be considered to choose an $\mathrm{AC}$ for using on water treatment, because these pore regions are important on adsorption of organic micro pollutants such as microcystins by activated carbons ${ }^{24,25}$.

According to Donati et al. $(1994)^{24}$, there is no correlation between adsorption capacity of activated carbon to microcystins and SSA, micropores volume and iodine number on activated carbon. However, mesopores on the carbons can improve microcystin adsorption. Pendleton et al. $(2001)^{25}$ also showed that in additional to the importance of mesopore volume, the adsorption capacity of the evaluated commercial activated carbons for removing microcystin was also influenced by the volumetric portion of secondary micropores. The volumetric portion of secondary micropores and mesopores of these carbons exceeded 37 and $28 \%$, respectively, and it facilitated adsorption of microcystin on $200.0 \mu \mathrm{g} \cdot \mathrm{mg}^{-1}$.

The commercial activated carbons from water treatment plant at hemodialysis centers presented volumetric portion of secondary micropores and mesopores of 0.30 to $0.32 \mathrm{~cm}^{3} \cdot \mathrm{g}^{-1}$ and of 0.03 to $0.04 \mathrm{~cm}^{3} \cdot \mathrm{g}^{-1}$, respectively. The results indicated the low quality of these adsorbents compared to those obtained from ACF.

According to Donati et al. (1994) and Pendleton et al. (2001) ${ }^{24,25}$, the removal of microcystin by activated carbons is favored by certain physical properties of these materials such as the volume of secondary micropores and mesopores. The activated carbons obtained from dried coconut shell endocarp and from wood, studied by these authors, showed volume of secondary micropores in the range of $0.10-0.13$ and $0.29-0.33 \mathrm{~cm}^{3} \cdot \mathrm{g}^{-1}$, and volume of mesopores in the range of $0.05-0.07$ and $0.26-0.40 \mathrm{~cm}^{3} \cdot \mathrm{g}^{-1}$, respectively.

Table 2. Textural properties of the commercial activated carbons and activated carbon fibers.

\begin{tabular}{lrrrrr}
\hline \multicolumn{1}{c}{ References } & \multicolumn{5}{c}{ Pore volume $\left(\mathrm{cm}^{3} \cdot \mathrm{g}^{-1}\right)$} \\
\cline { 2 - 6 } & $\begin{array}{c}\mathrm{SSA} \\
\left(\mathrm{m}^{2} . \mathrm{g}^{-1}\right)\end{array}$ & $\mathrm{V}_{\mathrm{p}}$ & $\mathrm{V}_{\text {mes }}$ & $\mathrm{V}_{\text {micr.2 }}$ & $\mathrm{V}_{\text {micr.1 }}$ \\
\hline MNS based ACF & $1,079.5$ & 0.58 & 0.20 & 0.30 & 0.07 \\
CS based ACF & $1,090.0$ & 0.57 & 0.21 & 0.27 & 0.08 \\
SCB based ACF & $1,174.3$ & 0.76 & 0.39 & 0.23 & 0.10 \\
UCM based ACF & $1,269.6$ & 0.67 & 0.12 & 0.50 & 0.05 \\
PWR based ACF & $1,550.1$ & 1.40 & 1.06 & 0.35 & 0.00 \\
Commercial AC B & 871.2 & 0.47 & 0.03 & 0.32 & 0.12 \\
Commercial AC F & 789.5 & 0.48 & 0.04 & 0.30 & 0.14 \\
NORIT GAC & 956.0 & 0.58 & 0.17 & 0.41 & 0.00 \\
\hline
\end{tabular}

SSA = Specific Surface Area $\left(\mathrm{m}^{2} \cdot \mathrm{g}^{-1}\right) ; \mathrm{V}_{\mathrm{p}}=$ Total volume of Pore $\left(\mathrm{cm}^{3} \cdot \mathrm{g}^{-1}\right)$, $\mathrm{V}_{\text {mes. }}=$ Volume of mesopore $\left(\mathrm{cm}^{3} \cdot \mathrm{g}^{-1}\right), \mathrm{V}_{\text {micr. } 2^{\circ}}^{\mathrm{p}}=$ Volume of secondary micropore $\left(\mathrm{cm}^{3} \cdot \mathrm{g}^{-1}\right)$ and $\mathrm{V}_{\text {micr. } .^{\circ}}=$ volume of primary micropore $\left(\mathrm{cm}^{3} \cdot \mathrm{g}^{-1}\right)$.
Taking these results as reference, it can be seen that the pine wood ACF obtained for our study presented a volume of secondary micropores of $0.35 \mathrm{~cm}^{3} \cdot \mathrm{g}^{-1}$ and a volume of mesopores of $1.06 \mathrm{~cm}^{3} \cdot \mathrm{g}^{-1}$, which represent an improvement in the group of available pores for the adsorption of complex molecules like microcystins of about $93.15 \%$. As for the ACF from dried coconut shell endocarp, this presented a volume of secondary micropores of $0.28 \mathrm{~cm}^{3} \cdot \mathrm{g}^{-1}$ and a volume of mesopores of $0.21 \mathrm{~cm}^{3} \cdot \mathrm{g}^{-1}$, representing an increase of $172.22 \%$ in the amount of available pores for the adsorption of those molecules. Thus, such as observed from Donati et al. (1994) ${ }^{24}$, our results also showed the dependence of the ACF porosity and the starting material.

\subsubsection{Surface functional groups by Fourier transform infrared spectroscopy (FTIR)}

The adsorption capacity of ACF is determined by their pore structures, but is also strongly affected by the presence of surface functional groups. The most common oxygenated groups on the ACF surface are carboxylic acids, carbonyls, quinones, phenolic hydroxyls, anhydrides, ethers, lactones and lactols ${ }^{26}$. Fourier transform infrared (FTIR) spectroscopy is a very useful tool for functional cluster analysis of the surface of carbon materials. FTIR was used in this work for characterization of the surface oxygen groups of ACF.

The FTIR spectra of the ACF were registered in wavelengths between 400 and $4000 \mathrm{~cm}^{-1}$. The experimental data were presented as a transmittance versus wavelength plot $\left(\mathrm{cm}^{-1}\right)$ and for spectrogram interpretation (Figure 2).

Therefore, the ACF from different raw materials obtained in this work had acid groups on their surfaces and were postulated to be carboxylic acids, lactones, carboxylic anhydrides, quinones and phenols. These groups can become ionized in water solution producing $\mathrm{H}^{+}$ions, and as a result, the pore surface of the ACF acquires negative charges.

\subsection{Adsorption kinetics and equilibrium of [D-Leucine ${ }^{1}$ ] MCYST-LR}

\subsubsection{Adsorption kinetics}

In order to determine the equilibrium time for adsorption of [D-Leucine ${ }^{1}$ ]MCYST-LR onto the ACF obtained from pine wood, sugarcane bagasse and dried coconut shell endocarp, a microcystin extract containing four microcystin variants was used, in which about $90 \%$ of the mass was composed of the variant [D-Leucine ${ }^{1}$ ] MCYST-LR ${ }^{14}$. The use of an extract containing four variants of the toxin prepared in potable water, allowed for simulation of the conditions found in natural waters, where there are competitions between the microcystins and other substances for the active sites of the ACF and commercial AC used.

The initial concentration of microcystin on the extract was much higher than that normally found in natural waters, which is about $50 \mu \mathrm{g} . \mathrm{L}^{-1[24]}$. However, high MCYST concentrations dissolved in water have been found in natural cyanobacteria bloom: Wisconsin (USA) $\left(200 \mu \mathrm{g} . \mathrm{L}^{-1}\right)$ and Australia $\left(1,800 \mu \mathrm{g} . \mathrm{L}^{-1}\right)^{27,28}$. Sivonen and Jones (1999) ${ }^{29}$ reported even higher concentrations of 25,000 $\mu \mathrm{g}$ MCYST/L in water from a natural bloom in Germany in 1997. These very high concentrations of MCYSTs also justified the use of microcystin levels between 6.0 and $11.0 \mathrm{mg} . \mathrm{L}^{-1}$ in the adsorption kinetics and equilibrium experiments in the present study. Furthermore, working with higher concentrations allowed their measurements in the liquid phase equilibrium above the detection limit of the HPLC system, which, in the present case, was $50 \mu \mathrm{g} . \mathrm{L}^{-1}$, avoiding sample concentration steps using $\mathrm{C} 18$ cartridges. 


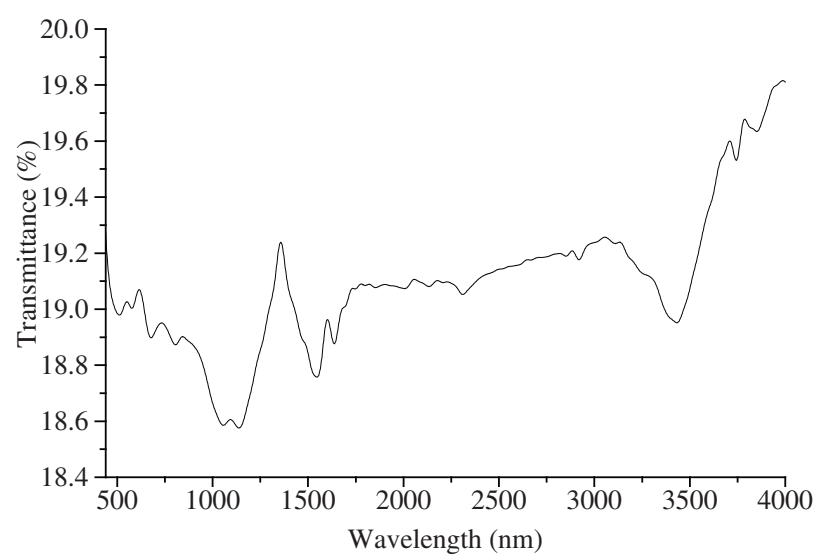

(a)

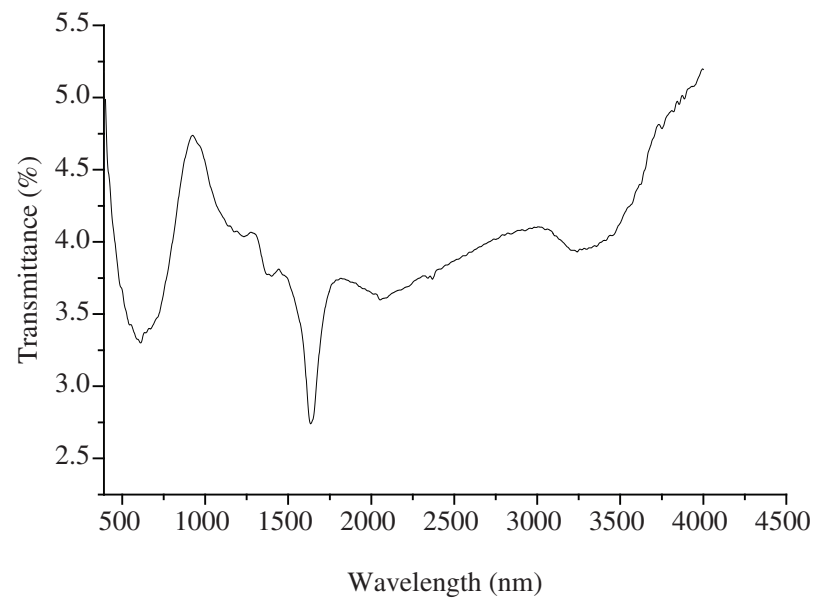

(c)

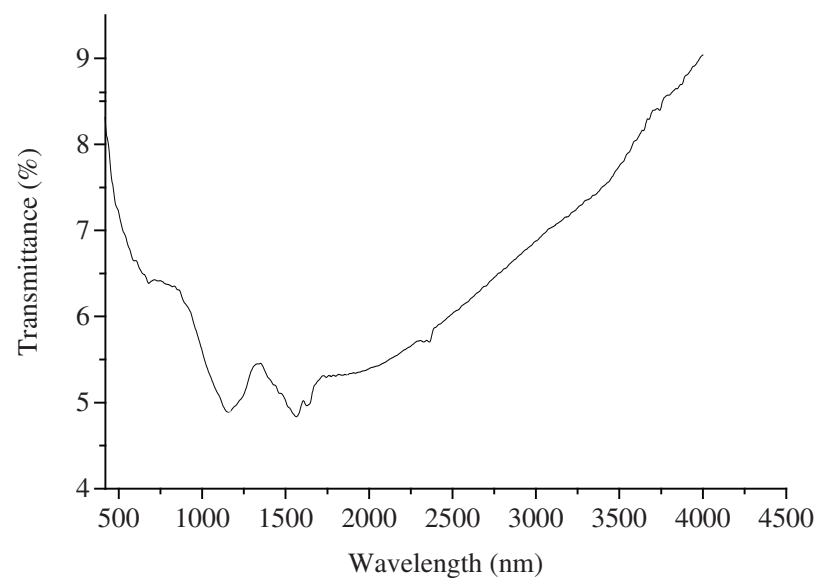

(e)

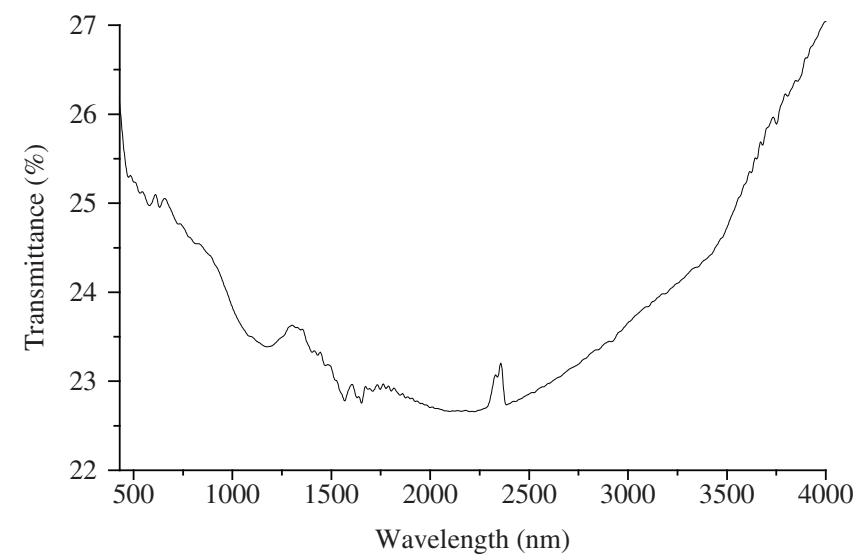

(b)

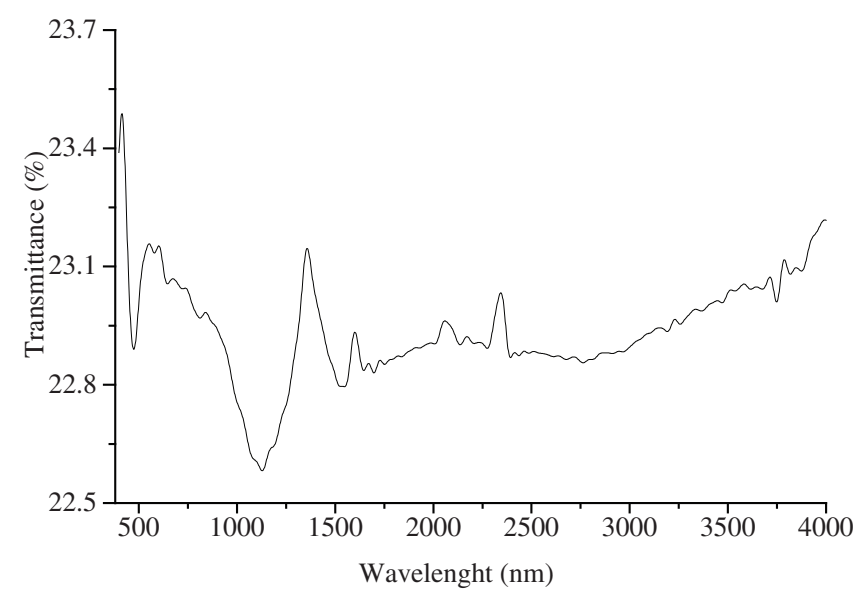

(d)

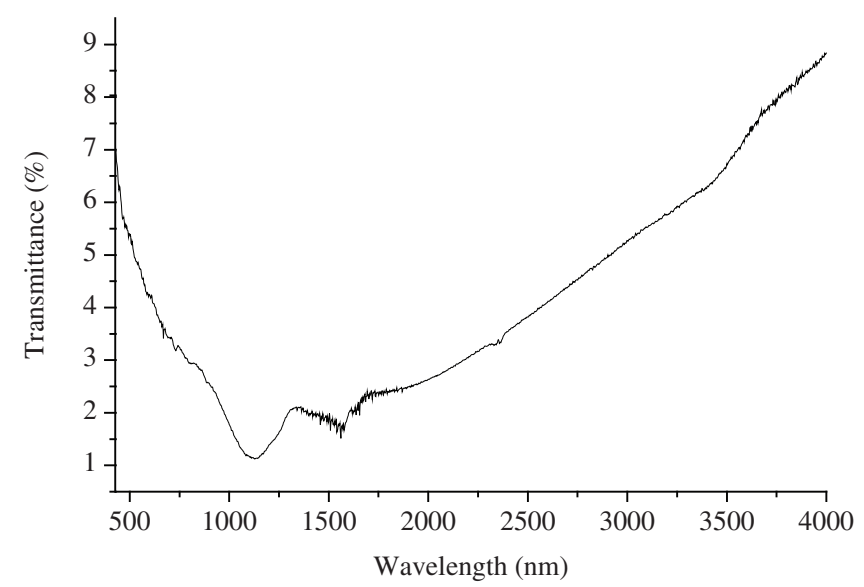

(f)

Figure 2. FTIR spectra of the a) ACF from UCM, b) CS, c) NORIT GAC, d) MNS, e) PWR and f) SCB.

Since there are few MCYST reference standards commercially available (MCYST -LR, -YR, -RR, -LA, -LW and -LF), theoretically only MCYST-LR could be quantified in the present study. According to Robillot et al. $(2000)^{30}$, the $\pi$-bonds conjugated in the ADDA fragment, common to all MCYSTs, are responsible for their UV absorption characteristics (Figure 3).
Thus, assuming that the coefficient of absorbance in the UV at $238 \mathrm{~nm}$ is identical for all the MCYSTs, but MCYSTs containing Tryptophane and Tyrosine, which could present absorbance peaks at 223 and $232 \mathrm{~nm}$, respectively, the [D-Leucine ${ }^{1}$ ]MCYST-LR can be quantified using the MCYST-LR standard reference. It is important to explain that such a technique is only valid for the quantification of 
MCYST that are analogues, and it cannot be used to identify these toxins, which require the use of mass spectrometry.

The evolution of the adsorption kinetics of [D-Leucine ${ }^{1}$ ] MCYST-LR onto the surface of the PWR ACF, SCB ACF and CS ACF showed a rapid adsorption kinetics for all the adsorbents so the equilibrium is established (Figure 4a).

The adsorption rate then gradually declined with time until adsorption equilibrium time was established at approximately 15,15 and 40 minutes for the PWR ACF, SCB ACF and CS ACF, respectively with removal efficiencies of the toxin in these intervals of $62.31 \%$ (CS ACF), 98.73\% (SCB ACF) and 99.27\% (PWR ACF).

For the commercial activated carbons from hemodialysis centers the equilibrium time was attained in 60 minutes for the B and F AC (Figure $4 \mathrm{~b}$ ). The removal efficiencies of the toxin for these carbons in equilibrium were $3.7 \%$ (B AC) and $4.3 \%$ (F AC). The low removal efficiencies for these last carbons are explained from their low volume of mesopore, about $0.04 \mathrm{~cm}^{3} \cdot \mathrm{g}^{-1}$, when compared to those found on the ACF (Table 2).

In recent publications, two papers reported on studies about the adsorption kinetics of MCYST-LR onto activated carbon materials. Pyu and Moon (2005), using activated carbon synthetic fibers to remove MCYST-LR, obtained up to $97 \%$ removal of the toxin from a solution with an initial concentration of $1,000 \mu \mathrm{g} . \mathrm{L}^{-1}$ of the toxin, after 5 minutes of contact time with $31 \mathrm{~g} . \mathrm{L}^{-1}$ of the fibers ${ }^{24}$. The authors observed an adsorption of $0.0321 \mu \mathrm{g} \cdot \mathrm{mg}^{-1}$ of the toxin by the best fiber in this time. Yan et al. (2006) ${ }^{32}$ showed that a solution with a $C_{0}=9,600 \mu \mathrm{g} . \mathrm{L}^{-1}$ of the same toxin, when treated with nano tubes of activated carbon $\left(1 \mathrm{~g} . \mathrm{L}^{-1}\right)$ with a diameter between 2 and $10 \mathrm{~nm}$, decreased the concentration to $3,700 \mu \mathrm{g} . \mathrm{L}^{-1}$ after 24 hours of contact time, giving an adsorption between 4.5 and $5.9 \mu \mathrm{g} \cdot \mathrm{mg}^{-1}$, with removal of MCYST-LR of up to $61.46 \%{ }^{25}$.

All these results which have been described on literature about removal efficiency of microcystins from water using commercial activated carbons provide results of low or near the expected efficien-

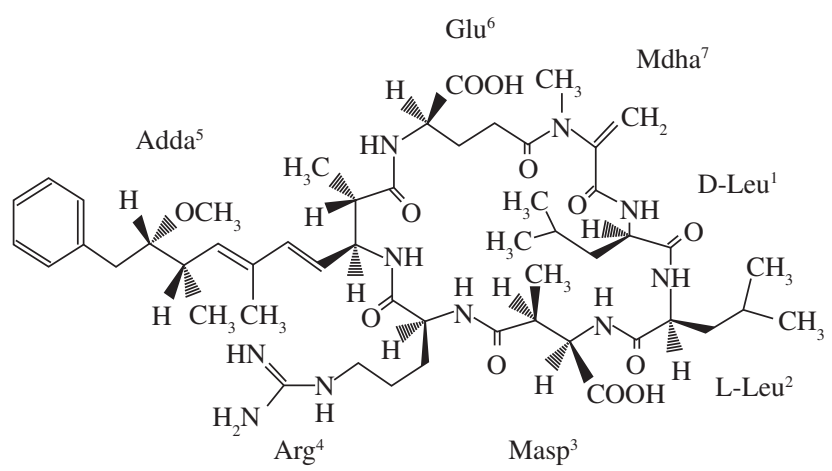

Figure 3. Structure of the [D-Leucine $\left.{ }^{1}\right]$ MCYST-LR. cies from those obtained for sugarcane bagasse, dried coconut shell endocarp and pine wood ACF produced for this work.

\subsubsection{Parameters of the kinetic models}

The straight-line plots of $\ln \left(q_{1}-q_{t}\right)$ versus $t$ for the Lagergren-firstorder model, $t$ /qt against $t$ for the pseudo-second-order model and the plots of qt versus $\ln (t)$ for the Elovich model for the adsorption of [D$\mathrm{Leu}^{1}$ ]MCYST-LR onto ACF and commercial activated carbons have been drawn to obtain the rate parameters (graphics not shown).

It can be easily seen from Table 3 , the correlation coefficients $\left(\mathrm{r}_{1}^{2}\right)$, for the Lagergren-first-order and the Elovich kinetic models are lower than that of the pseudo-second-order kinetic model. This is probable

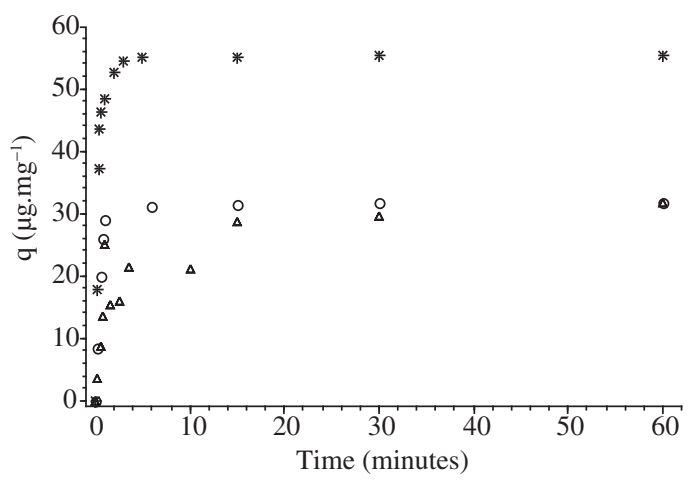

(a)

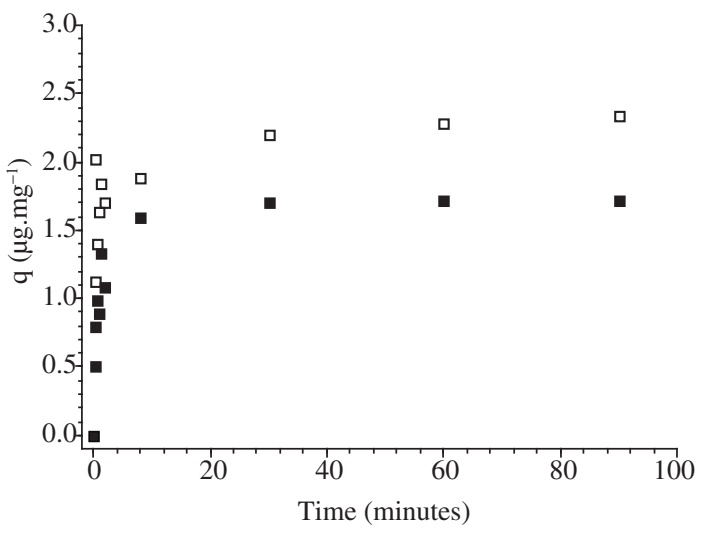

(b)

Figure 4. a) Adsorption kinetics of [D-Leucine $\left.{ }^{1}\right]$ MCYST-LR from PWR $\mathrm{ACF}$ 米, $\mathrm{CS} \mathrm{ACF} \circ$, SCB ACF $\triangle$, and b) $\mathrm{ACF} \square$ (water treatment plant from hemodialysis center of the Clinical Hospital at Federal University of Pernambuco, Brazil), AC B (water treatment plant from hemodialysis center of the Clinical Hospital at State University of Campinas, Brazil).

Table 3. Parameters of the kinetic models of Lagergren-first-order, Pseudo-second-order and Elovich.

\begin{tabular}{|c|c|c|c|c|c|c|}
\hline Moldels & $\begin{array}{c}\text { Kinetic } \\
\text { parameters }\end{array}$ & $\begin{array}{c}\mathrm{CS} \\
\mathrm{ACF} \\
\end{array}$ & $\begin{array}{l}\mathrm{SCB} \\
\mathrm{ACF} \\
\end{array}$ & $\begin{array}{l}\text { PWR } \\
\text { ACF } \\
\end{array}$ & $\begin{array}{c}\text { Commercial } \\
\text { AC B }\end{array}$ & $\begin{array}{c}\text { Commercial } \\
\mathrm{AC} \mathrm{F}\end{array}$ \\
\hline \multirow[t]{3}{*}{ Lagergren-first-order } & $\mathrm{k}_{1}$ (per minute) & 0.088 & 0.167 & 0.425 & 0.131 & 0.086 \\
\hline & $\mathrm{q}_{1}\left(\mu \mathrm{g} \cdot \mathrm{mg}^{-1}\right)$ & 31.66 & 31.66 & 55.21 & 1.72 & 2.2 \\
\hline & $\mathrm{r}_{1}^{2}$ & 0.86 & 0.90 & 0.76 & 0.89 & 0.84 \\
\hline \multirow[t]{3}{*}{ Pseudo-second-order } & $\mathrm{k}_{2}\left(\mathrm{mg} \cdot \mu \mathrm{g}^{-1} / \mathrm{min}\right)$ & 0.013 & 0.120 & 0.162 & 0.809 & 0.602 \\
\hline & $\mathrm{q}_{2}\left(\mu \mathrm{g} \cdot \mathrm{mg}^{-1}\right)$ & 33.33 & 32.26 & 55.55 & 1.74 & 2.29 \\
\hline & $\mathrm{r}_{2}^{2}$ & 0.99 & 0.99 & 1.00 & 0.99 & 0.99 \\
\hline \multirow[t]{3}{*}{ Elovich } & $\alpha\left(\mu \mathrm{g} \cdot \mathrm{mg}^{-1} / \mathrm{min}\right)$ & 63.41 & $3.7 \times 10^{3}$ & $6.5 \times 10^{4}$ & 43.7 & $3.16 \times 10^{2}$ \\
\hline & $\beta\left(\mathrm{mg} \cdot \mu \mathrm{g}^{-1}\right)$ & 0.201 & 0.318 & 0.219 & 5.291 & 4.901 \\
\hline & $\mathrm{r}_{\mathrm{E}}^{2}$ & 0.95 & 0.62 & 0.64 & 0.95 & 0.95 \\
\hline
\end{tabular}


that the adsorption system is not followed by the Lagergren-first-order or Elovich kinetic models, it is fitted the pseudo-second-order kinetic model. The calculated $\mathrm{q}_{2}$ values agree with experimental $\mathrm{q}_{\mathrm{t}}$ values, and also, the correlation coefficients for the pseudo-second-order kinetic plots were very high than the $r_{2}^{2}$ values of the other kinetic models.

\subsubsection{Adsorption equilibrium experiments}

The adsorption equilibrium isotherms (Figure 5) obtained for the adsorption of [D-Leucine ${ }^{1}$ MCYST-LR onto the surface of the ACF from pine wood and sugarcane bagasse showed a variation in their adsorption capacities, dependent on the physical characteristics of the adsorbents such as volume of mesopore.

With respect to the adsorption equilibrium of MCYSTs on activated carbons, has been observed Donati et al. (1994) and Pendleton et al. $(2001)^{24,25}$ observed that the adsorption capacity of the activated carbons for MCYSTs depended on the volumes of secondary micropores and mesopores. In the present study, the same tendency described by these authors was observed for the adsorption behavior for PWR ACF and SCB ACF, the greater the volumes of secondary micropores and mesopores of the ACF, the greater their capacity to adsorb MCYST. Adding up the volumes of secondary micropores and mesopores, total volumes of 1.40 and $0.74 \mathrm{~cm}^{3} \cdot \mathrm{g}^{-1}$ were obtained for the PWR ACF and SCB ACF, respectively, explaining why the former showed a greater adsorption affinity for the toxin than the latter.

One cannot ignore the effect of the interactions of functional groups on the surface of these adsorbents on adsorption of microcystins. In the $\mathrm{pH}$ range around that used in the present experiments $(\approx 6-8.5)$, it was to be expected that in solution the [D-Leucine ${ }^{1}$ ] MCYST-LR would present the following charge difference " -1 " $(--\&+)$, resulting from dissociation of the carboxyl groups $\left(\mathrm{COO}^{-}\right)$ of the D-glutamate and D-Erythro- $\beta$-Methylaspartic acid, and the positive charge being due to protonization of the basic amino acid $\mathrm{NH}^{+}$group of the Arginine. These differences could result in different adsorption characteristics. An earlier investigation using Fourier transformed infrared (FTIR) spectroscopy showed that the surface of the ACF presented functional groups of an acid nature (section 3.1.2). In the same $\mathrm{pH}$ range mentioned above, the surface groups of the $\mathrm{ACF}$ also dissociated, resulting in an affinity for the positive groups of the microcystin. Such a prerogative leads to the idea that adsorption of the toxin onto the surface of the carbons also could be via electrostatic interactions.

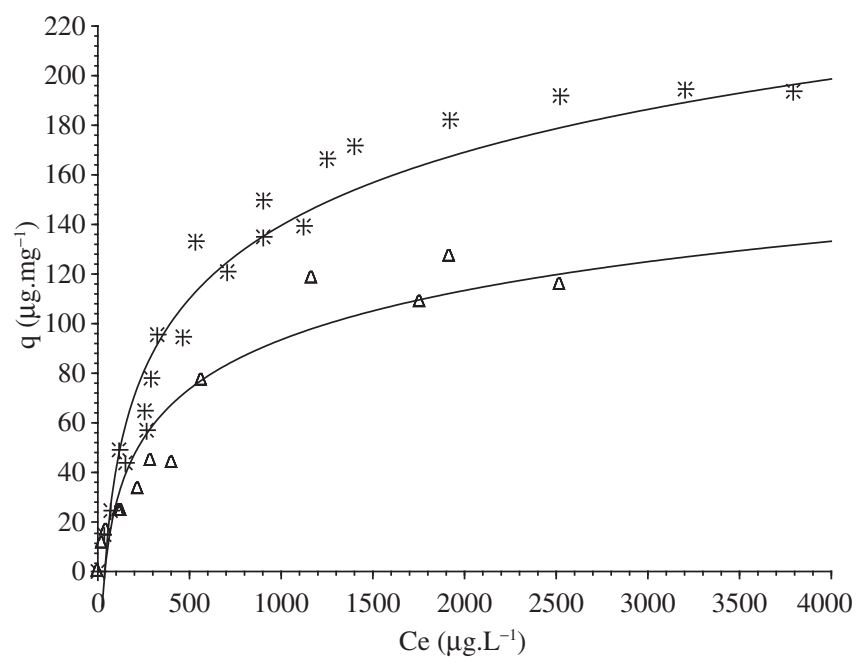

Figure 5. Adsorption equilibrium of [D-Leucine ${ }^{1}$ ]MCST-LR onto the surface 米 pine wood ACF and $\Delta$ sugarcane bagasse ACF.
Donati et al. (1994) ${ }^{24}$ evaluated wood activated carbons for the adsorption of MCYST-LR (one of the microcystin variants) in pure water and in river water. Their experimental data were fitted to the Langmuir's model, whose maximum adsorption capacities for these wood carbons were $220 \mu \mathrm{g} . \mathrm{mg}^{-1}$ (pure water) and $280 \mu \mathrm{g} \cdot \mathrm{mg}^{-1}$ (river water). The mesopore volumes of the two carbons were 0.27 and $0.40 \mathrm{~cm}^{3} \cdot \mathrm{g}^{-1}$, respectively. In this study, for the first time the pore range of the activated carbons was associated with the adsorption effectiveness of the activated carbons in the removal of MCYSTLR. Pendleton et al. (2001) ${ }^{25}$ arrived at the same conclusion with respect to the microporosity of the activated carbons when evaluating the removal of MCYST-LR by such carbons from wood and dried coconut endocarp. Their results showed that those carbons with a proportionally greater mesopore volume provided greater removal of the toxin from water. In addition, these authors reported on a small range of pores existing on the surface of the activated carbons that contributed to the adsorption of the toxin from the water together with the mesopores, and called these pores secondary micropores.

In the studies developed by Pendleton et al. $(2001)^{25}$ the chemically activated wood carbons presented adsorption onto the monolayer of between 172 and $204 \mu \mathrm{g} . \mathrm{mg}^{-1}$. The authors varied the initial MCYST-LR concentration between 0.07 and $3.03 \mathrm{mg} . \mathrm{L}^{-1}$ in these experiments using PAC from wood, and the activated carbon concentration was approximately $8 \mathrm{mg} . \mathrm{L}^{-1}$ in all the experiments. The authors did not carry out a kinetic study to determine the equilibrium time, but simply left the flasks containing the MCYSTLR and carbon for a period of 72 hours, and then determined the equilibrium toxin concentration and the adsorption capacities of the carbons in this time.

In our experiments was used microcystin extract with four variants of this toxin, which shown [D-Leucina $\left.{ }^{1}\right]$ MCYST-LR in the proportion of $90 \%\left(\mathrm{~m} . \mathrm{m}^{-1}\right)$, differently of the last authors cited which used a solution prepared from MCYST-LR standard reference.

Some years earlier, Mohamed et al. (1998) $)^{33}$, also evaluated powdered and granulated active carbons from wood as potential adsorbents to remove MCYSTs from water. After fitting to the Freundlich's model, their experimental data showed a relative adsorption capacity $\left(\mathrm{k}_{\mathrm{F}}\right)$ between 0.50 and 6.31 L.mg ${ }^{-1}$ (powdered AC, MCYST-

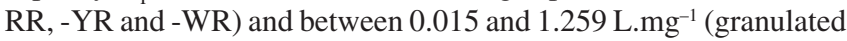
AC, MCYST- LR and -Lharg). The mass of carbon used by these authors varied between $100 \mathrm{mg}$ and $500 \mathrm{mg}$ per liter of solution, which contained an initial toxin concentration of $2 \mathrm{mg} . \mathrm{L}^{-1}$, and the contact time was 7 days.

When the experimental data for the adsorption of [D-Leucine $\left.{ }^{1}\right]$ MCYST-LR by the activated carbon fibers from sugar cane bagasse and pine wood were fitted to the Langmuir and Freundlich's models, was possible to calculate the parameters of the two models (Table 4). The good affinity of these ACF for the toxin became apparent, when compared to the results obtained by Mohamed et al. $(1998)^{33}$, who used an extract containing up to 3 variants of microcystin.

Table 4. Parameters of the Langmuir's and Freundlich's adsorption models.

\begin{tabular}{clcc}
\hline Models & Parameters & PWR ACF & SCB ACF \\
\hline Langmuir & $\mathrm{R}_{\mathrm{L}}{ }^{2}$ & 0.98 & 0.97 \\
& $\mathrm{k}_{\mathrm{L}}\left(\mathrm{L}^{\mathrm{m}} \mathrm{mg}^{-1}\right)$ & 2.23 & 1.33 \\
& $\mathrm{q}_{\mathrm{m}}\left(\mu \mathrm{g} \cdot \mathrm{mg}^{-1}\right)$ & 200.0 & 161.3 \\
& $\mathrm{R}_{\mathrm{F}}{ }^{2}$ & 0.92 & 0.90 \\
Freundlich & $\mathrm{K}_{\mathrm{F}}\left(\mathrm{L} \cdot \mathrm{mg}^{-1}\right)$ & 1.73 & 1.55 \\
& $1 / \mathrm{n} / \mathrm{n}$ & $2.07 / 0.48$ & $1.79 / 0.5$ \\
\hline
\end{tabular}




\subsection{Experiments on ACF fixed-bed}

Because are used on water treatment at hemodialysis centers, activated carbons $\mathrm{B}$ and $\mathrm{F}$ were tested on adsorption continuous process of the [D-Leucine $\left.{ }^{1}\right]$ MCYST-LR together ACF from dried coconut shell endocarp and sugarcane bagasse. Adsorption capacities of the fixed-bed were studied from breakthrough curves, which are showed on the Figure 6.

Initially, the adsorbent layer situated in the lower part of fixed-bed adsorbed rapidly the microcystin, reducing effectively the concentration this toxin in the exit of the column. In this situation, the column top stayed practically solute free. After some time, the lower layer began to saturate of solute and adsorption occurred in an adsorption zone (Zad) relatively closed and the microcystin concentration in the exit of the column rapidly changed. Thus, the adsorption zone

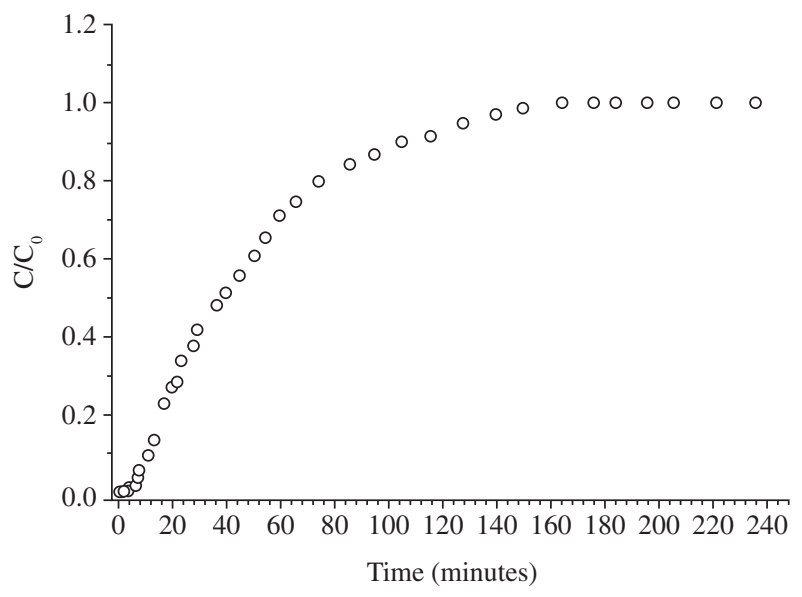

(a)

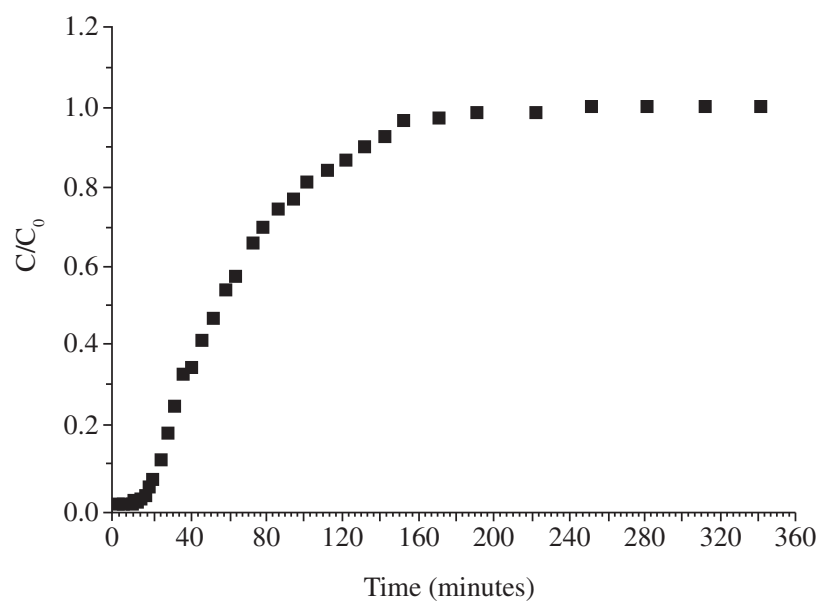

(c) moving up such as a wave, under a rate ordinarily much slower than the straight velocity of the fluid trough fixed-bed. When the Zad reached the top of the column, and the solute concentration rising sensitively, the system was told starting breakthrough $\left(\mathrm{C} / \mathrm{C}_{0}=0.05\right)$. So the [D-Leucine ${ }^{1}$ MCYST-LR concentration in the exit of the column started rising rapidly when the Zad pass through column base to top up to observe that microcystin concentration in the exit of the column is equal to microcystin concentration in the feed column, e.g., $\mathrm{C} / \mathrm{C}_{0}=1$.

From data obtained of the breakthrough curves was possible to calculate operation useful $\left(\mathrm{t}_{5 \%}\right)$ and exhaustion $\left(\mathrm{t}_{\mathrm{t}}\right)$ time of the fixedbed for microcystin removing, furthermore useful $\left(Q_{u}\right)$ and exhaustion $\left(Q_{t}\right)$ capacities of each fixed-bed also were calculated (Table 5).

From results of the Table 5, generated from breakthrough curves, it is possible to observe a difference on useful and total adsorption

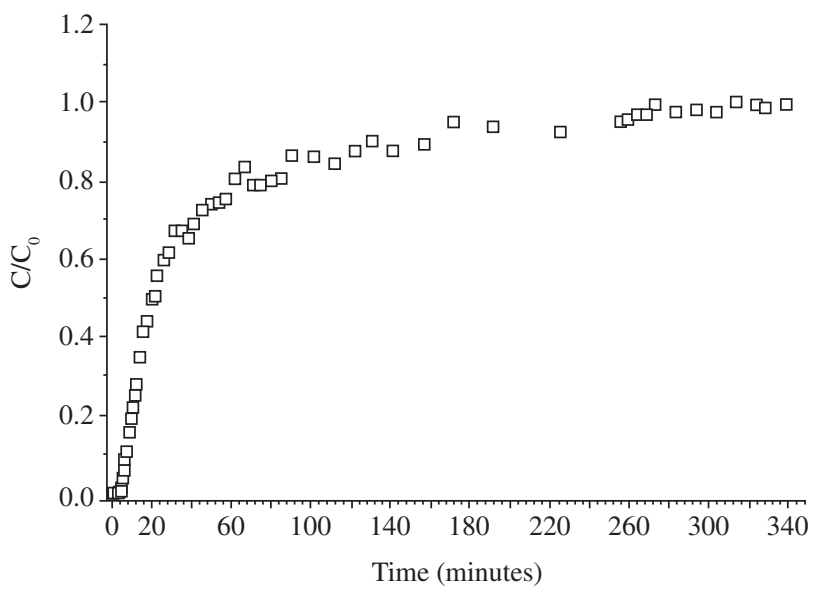

(b)

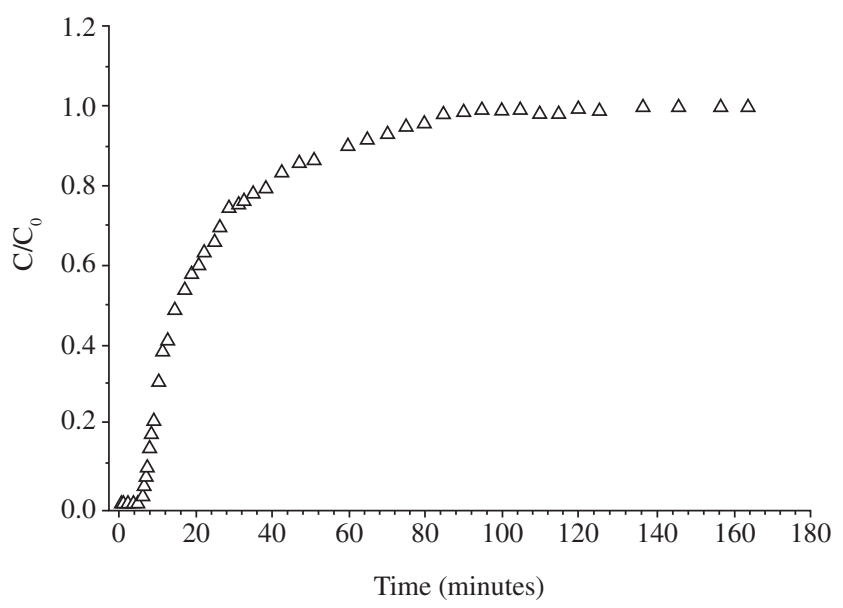

(d)

Figure 6. Breakthrough curves: a) SCB ACF (०), b) B AC ( $\square)$, c) F AC (匹), and d) CS ACF ( $\Delta$ ).

Table 5. Parameters dynamic adsorption of the [D-Leucine $\left.{ }^{1}\right]$ MCYST-LR on fixed-bed.

\begin{tabular}{lccccc}
\hline \multirow{2}{*}{ Ref. } & \multicolumn{5}{c}{ Parameters of dynamic adsorption on fixed-bed } \\
\cline { 2 - 6 } & $\mathrm{t}_{5 \%}($ minutes $)$ & $\mathrm{t}_{\mathrm{t}}$ (minutes $)$ & $\mathrm{Q}_{\mathrm{u}}\left(\mu \mathrm{g} \cdot \mathrm{mg}^{-1}\right)$ & $\mathrm{Q}_{\mathrm{t}}\left(\mu \mathrm{g} \cdot \mathrm{mg}^{-1}\right)$ & 1.88 \\
SCB ACF & 9 & 165 & 0.92 & 4.11 & $\mathrm{H}_{\mathrm{UNB}}$ \\
CS ACF & 7.5 & 80 & 0.78 & 10.12 & 1.89 \\
B AC & 7 & 320 & 2.00 & 8.02 & 2.15 \\
F AC & 24 & 282 & 1.77 \\
\hline
\end{tabular}


capacity from each fixed-bed, which is explained by porosity of the ACF and commercial AC. The SCB ACF had higher mesopore and secondary micropore volume when compared to others carbons, then the fixed-bed this ACF shown rapidly adsorption of toxin, at 165 minutes of process, was observed an total capacity on $12.82 \mu \mathrm{g} \cdot \mathrm{mg}^{-1}$, in contrast to commercial AC from hemodialysis centers ( $\mathrm{B}$ and $\mathrm{F}$ ) which had lower mesopore and secondary micropore presented exhaustion capacity of 10.12 at 7 and 24 minutes.

The mass transfer parameter estimated from data of the breakthrough curves $\left(\mathrm{H}_{\mathrm{UNB}}\right)$ is also showed in Table 5. Small values this parameter mean that the breakthrough curve is close to an ideal step with negligible mass-transfer resistance. As breakpoint was reached in the first minutes of the runs, adsorption zone estimated is close to the bed height, what do not guarantee a good development of mass transfer zone through the beds.

\section{Conclusions}

The structures of ACF from MNS, CS and UCM are well suited to produce microporous ACF, with a micropore area between 1014.2 and $1245.8 \mathrm{~m}^{2} \cdot \mathrm{g}^{-1}$ and a micropore volume between 0.34 and $0.55 \mathrm{~cm}^{3} \cdot \mathrm{g}^{-1}$, while the structures of SCB and PWR are well suited to the production of mesoporous ACF with a mesopore area between 77.3 and $342.5 \mathrm{~m}^{2} . \mathrm{g}^{-1}$ and a mesopore volume between of 0.39 and $1.06 \mathrm{~cm}^{3} \cdot \mathrm{g}^{-1}$.

The adsorption of [D-Leucine ${ }^{1}$ MCYST-LR molecule onto $\mathrm{ACF}$ and commercial AC follows the pseudo-second-order kinetic model. The experimental data have also been applied to predict the rate constants of adsorption and the adsorption capacities. Thus, in these studies the ACF from sugarcane bagasse and pine wood showed monolayer adsorption of 161.3 and $200.0 \mu \mathrm{g} . \mathrm{mg}^{-1}$, respectively. When compared with other results available in the literature, these results gave an idea of the profile of the carbon or ACF that should be used in water treatment plants to remove contaminants like MCYSTs, requiring a volume of secondary micropore above of $0.35 \mathrm{~cm}^{3} \cdot \mathrm{g}^{-1}$ and volume of mesopore greater than $0.40 \mathrm{~cm}^{3} \cdot \mathrm{g}^{-1}$.

Commercial activated carbons used on water treatment plant at hemodialysis centers were sampled and their textural properties and removal efficiency of [D-Leucine $\left.{ }^{1}\right]$ MCYST-LR were studied. These AC presented SSA of 789.56 and $871.2 \mathrm{~m}^{2} . \mathrm{g}^{-1}$, volume of mesopore between 0.03 and $0.04 \mathrm{~cm}^{3} \cdot \mathrm{g}^{-1}$ below from specified by literature $\left(0.40 \mathrm{~cm}^{3} \cdot \mathrm{g}^{-1}\right)$. From theses results, both carbons may to be used with caution.

The low efficiency for removing microcystins from commercial AC used on water treatment plants of Brazilian hemodialysis centers is linked mainly to the volume of mesopore of those adsorbents, which were closer to $0.04 \mathrm{~cm}^{3} \cdot \mathrm{g}^{-1}$.

Studies about dynamic adsorption of [D-Leucine $\left.{ }^{1}\right]$ MCYST-LR on fixed-bed commercial AC showed adsorption capacity between 3.67 and $5.31 \mu \mathrm{g} . \mathrm{mg}^{-1}$, while the fixed-bed CS and SCB ACF presented maximum adsorption of microcystin between 4.11 and $12.82 \mu \mathrm{g} . \mathrm{mg}^{-1}$, respectively. It was observed breakpoint on first minutes of run, what do not guaranteed a good development of mass transfer zone on the beds.

\section{Acknowledgements}

The authors are grateful for the financial support received from the following Brazilian developmental agencies: FAPESP (Research Support Agency of the State of São Paulo, São Paulo, Brazil); CNPq (National Research Council); CAPES (Graduate Progress Coordination).

\section{References}

1. Honda RY, Mercante CTJ, Vieira JMS, Esteves KE, Cabianca MAA Azevedo MTP. Cianotoxinas em pesqueiros da região metropolitana de
São Paulo. In: Esteves KE, Sant'Anna CL. (Org.). Pesqueiros sob uma visão integrada de meio ambiente, saúde pública e manejo. São Carlos: Rima; 2006. p. 105-120.

2. Sant'anna CL, Azevedo MTD. Contribution to the knowledge of potentially toxic Cyanobacteria from Brazil. Nova Hedwigia. 2000; 71(3-4):359-385.

3. Landsberg JH. The effects of harmful algal blooms on aquatic organisms. Reviews in Fisheries Science. 2002; 10(2):113-390.

4. Hoffman JRH. Removal of Microcystis toxins in water purification process. Water S.A. 1976; 2(2):58-60.

5. Keijola AM, Himberg K, Esala AL, Sivonen K, Hiisvirta L. Removal of cyanobacterial toxins in water-treatment processes - laboratory and pilot-scale experiments. Toxicity Assessment. 1988; 3(5):643-656.

6. Falconer IR, Runnegar MTC, Buckley T, Huyn VL, Bradshaw P. Use of powdered and granular activated carbon to remove toxicity from drinking water containing cyanobacterial toxins. Journal American Water Works Association. 1989; 18(2):102-105.

7. Himberg K, Keijola AM, Hiisvirta L, Pyysalo H, Sivonen K. The effect of water treatment processes on the removal of hepatotoxins from Microcystis and Oscillatoria cyanobacteria: a laboratory study. Water Research. 1988; 23(8):979-984.

8. BRASIL. Ministério do Desenvolvimento, Indústria e Comércio Exterior do Brasil. Importation and exportation of activated carbon from Brazil. Available from: http://aliceweb.desenvolvimento.gov.br. Accessed on: January 2005.

9. Matthiensen A, Beattie KA, Yunes JS, Kaya K, Codd GA. [D-Leu(1)] microcystin-LR, from the cyanobacterium Microcystis RST 9501 and from a Microcystis bloom in the Patos Lagoon estuary, Brazil. Phytochemistry. 2000; 55(5):383-387.

10. Oliveira ACR, Magalhães SVF, Soares RM, Azevedo SMFO. Influence of drinking water composition on quantitation and biological activity of dissolved microcystin (Cyanotoxin). Environmental toxicology. 2005; 20(2):126-130.

11. Albuquerque-Jr EC, Mendez MO, Coutinho AR, Franco TT. Production and characterization of activated carbon from Brazilian agricultural residues. In: Castro AT (ed.). Proceedings of the third Brazilian Carbono Congress; 2005 November 7-11; Rio de Janeiro, Brazil. Rio de Janeiro: Department of Science and Thecnology and Thecnological Center of the Brazilian Army; 2005. p. 401-410.

12. Webb PA, Orr C. Surface area and pore structure by gas adsorption. In: Analytical methods in fine particle technology. Atlanta: Micromeritics Instrument Corp. Atlanta; 1997. 301 p.

13. Kuroda EK, Albuquerque-Jr EC, Di Bernardo L, Trofino JC. Caracterização e escolha do tipo de carvão ativado a ser empregado no tratamento de águas contendo microcistinas. In: Brazilian Association of Sanitation and Environmental Engineering (ed.). Brazilian Environmental Sanitation: utopia or reality? Proceedings of the twentieth third Brazilian Congrees of Sanitary and Environmental Engineering; 2005 18-23; Mato Grosso, Brazil. Campo Grande: Brazilian Association of Sanitary and Environmental Engineering; 2005. p. 1-10.

14. Albuquerque-Jr EC, Melo LFC, Franco TT. Use of solid-phase extraction, high-performance liquid chromatography, and MALDI-TOF identification for [D-Leu ${ }^{1}$ MCYST-LR analysis in treated water: Validation of the analytical methodology. Canadian Journal of Analytical Sciences \& Spectroscopy. 2007; 52(1). (in press).

15. Ruthven DM, Goddard M. Sorption and diffusion of C-8 aromatichydrocarbons in faujasite type zeolites .1. equilibrium isotherms and separation factors. Zeolites. 1986; 6(4):275-282.

16. Ho YS, McKay G. Pseudo-second order model for sorption processes. Process. Biochem. 1999; 34(5):451-465.

17. Ho YS, McKay G. Kinetic models for the sorption of dye from aqueous solution by wood. J. Environ. Sci. Health Part B: Process Safety Environ. Protect. 1998; 76(B2):183-191.

18. Low MJD. Kinetics of chemisorption of gases on solids. Chem. Rev. 1960; 60(3):267-312. 
19. Chien SH, Clayton WR. Application of Elovich equation to the kinetics of phosphate release and sorption in soils. Soil Sci. Soc. Am. J. 1980; 44(2):265-268.

20. Santos ES, Guirardello R, Franco TT. Preparative chromatography of xylanase using expanded bed adsorption. Journal of chromatography A. 2002; 944(1-2):217-224.

21. Barros MASD, Zola AS, Arroyo PA, Aguiar EFS, Tavares CRG. Equilibrium and dynamic ion exchange studies of $\mathrm{Cr}^{3+}$ on zeolites $\mathrm{NaA}$ and NaX. Acta Scientiarum. 2002; 24(6):1619-1625.

22. Geankoplis CJ. Transport Processes and Separation Process Principles. 4 ed. USA: PTR Prentice Hall; 2003.

23. Quinlivan PA, Li L, Knappe DRU. Effects of activated carbon characteristics on the simultaneous adsorption of aqueous organic micropollutants and natural organic matter. Water Research. 2005; 39(8):1663-1673.

24. Donati C, Drikas M, Hayes R, Newcombe G. Microcystin-LR adsorption by powdered activated carbon. Water Research. 1994; 28(8):1735-1742.

25. Pendleton P, Schumann R, Wong SH. Microcystin-LR adsorption by activated carbon. Journal of Colloid and Interface Science. 2001; 240(1):1-8.

26. Toles CA, Marshall WE, Johns MM. Surface functional groups on acidactivated nutshell carbons. Carbon. 1999; 37(8):1207-1214.

27. Mcdermott CM, Feola R, Plude J. Detection of cyanobacterial toxins (microcystins) in waters of northeastern Wisconsin by a new immunoassay technique. Toxicon. 1995; 33(11):1433-1442.

28. Ueno Y, Nagata S, Tsutsumi T, Hasegawa A, Yoshida F, Suttajit M, Mebs D, Pütsch M, Vasconcelos V. Survey of microcystins in environmental water by a highly sensitive immunoassay based on monoclonal antibody. Natural toxins. 1996; 4(6):271-276.
29. Sivonen K, Jones G. Cyanobacterial toxins. In: Toxic Cyanobacteria in Water: A guide to their public health consequences, monitoring and management. Ingrid Chorus and Jamie Bartram (ed.). Routledge, UK: E\&FN Spon; 1999. p. 55-124.

30. Robillot C, Vinh J, Puiseux-Dao S, Hennion MC. Hepatotoxin Production Kinetics of the Cyanobacterium Microcystis aeruginosa PCC 7820, as Determined by HPLC-Mass Spectrometry and Protein Phosphatase Bioassay. Environmental Science \& Technology. 2000; 34(16):3372-3378.

31. Pyo D, Moon D. Adsorption of microcystin LR by activated carbon fibers. Bulletin of the Korean Chemical Society. 2005; 26(12):2089-2092.

32. Yan H, Gong A, He H, Zhou J, Wei Y, Lv L. Adsorption of microcystins by carbon nanotubes. Chemosphere. 2006; 62(1):142-148.

33. Mohamed ZA, Carmichael WW, An J, El-Sharouny HM. Activated carbon removal efficiency of microcystins in an aqueous cell extract of Microcystis aeruginosa and Oscillatoria tenuis strains isolated from Egyptian freshwaters. Environmental toxicology. 1999; 14(1):197-201.

\section{Nomenclature}

ACF - Activated Carbon Fiber

PWR - Pine Wood Residues

MNS - Macadamia Nut Shell

CS - Dried Coconut Shell Endocarp

UCM - Unripe Coconut Mesocarp

SCB - Sugar Cane Bagasse

AC - Activated carbon

GAC - Granulated Activated Carbon

NORIT GAC - Commercial Activated Carbon used like reference sample.

$\mathrm{H}_{\mathrm{UNB}}$ - Height of unused bed 